\title{
Long-Term Surgical Outcomes of Transobturator Tape Procedure in Women With Mixed Urinary Incontinence
}

\author{
Miks Üriner Inkontinansı Olan Kadınlarda Transobturator Band Uygulamasının Uzundönem Cerrahi Sonuçları
}

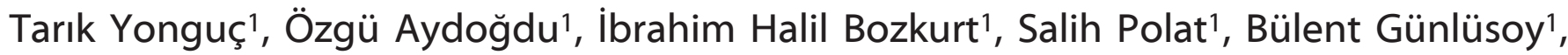
Volkan Șen 1 , Tansu Değirmenci', Burak Arslan² '/zmir Bozyaka Training and Research Hospital, Urology Clinic, Izmir
2 Haseki Training and Research Hospital, Urology Clinic, Istanbul

Received:Dec 5,2014• Accepted: April 24,2015

\section{Corresponding Author}

Özgü Aydoğdu

GSM: 05326721012

E-mail: ozgucan@yahoo.com

Izmir Bozyaka Training and Research Hospital, Urology Clinic Karabaglar, Izmir

Objective: To evaluate postoperative outcomes and complications of transobturator tape (TOT) procedure in the treatment of patients with mixed urinary incontinence (MUI).

Materials and methods: We analyzed 193 consecutive female patients who underwent TOT procedure. Among these patients 75 women with MUI were the subjects of this study. All patients were evaluated with the International Consultation on Incontinence Questionnaire-Short form (ICIQ-SF) preoperatively and at the postoperative follow-up visits. Patient satisfaction was evaluated with Visual analog scale. On the postoperative 15th day, all patients were routinely evaluated with urine culture and possible early postoperative complications were examined. Patients were evaluated on the postoperative 3rd, 12th months and annually with pelvic examination, VAS, cough stress test (CST) and ICIQ-SF. Surgical outcomes were evaluated and data of subjective and objective cure rates, any complications related to the procedure were registered. Statistical analyses were performed with SPSS 17.0 (SPSS version 17.0, Chicago, IL, USA).

Results: A total of 67 women who met the requirements for inclusion and who had available records for analysis were included in the study. Objective cure, subjective cure and patient satisfaction rates were 89.6, 53.7 and $70.1 \%$ respectively. The mean score for 29 patients with a postoperative 5 th year ICIQ-SF score $>0$ was 12.2 (SD \pm 4.2 ). Of the 67 patients, the urgency urinary incontinence (UUI) component of 12 patients $(17.9 \%)$ had improved postoperatively. Fifty-five $(82 \%)$ patients with persistent UUI postoperatively were treated with antimuscarinic drugs. None of our patients experienced intraoperative complications. Two (3\%) patients required re-operation for recurrent stress urinary incontinence (SUI) in the follow-up.

Conclusion: TOT procedure is successful for surgical treatment of MUI with predominant SUI in long-term follow-up. The operation was satisfactory for the most of the women. Persistence of UUI was the main reason for dissatisfaction.

Key Words: TOT, mixed urinary incontinence, stress urinary incontinence

Amaç: Miks üriner inkontinansı (MÜi) olan hastalarda transobturator bant (TOT) ișlemine ait postoperative sonuçlar ve komplikasyonların değerlendirilmesi.

Gereç ve yöntem: TOT yapılan 193 kadın hasta değerlendirildi. Bu hastalardan Müi olan 75 kadın hasta incelendi. Tüm hastalar preoperatif dönemde ve postoperatif kontrollerde International Consultation on Incontinence Questionnaire-Short formunu (ICIQ-SF) ile değerlendirildi. Postoperatif hasta memnuniyet visual analog scale (VAS) ile değerlendirildi. Tüm hastalar postoperatif 15. günde idrar kültürü ile ve olası postoperatif erken komplikasyonlar açısından değerlendirildi. Hastalar postoperatif 3. ve 12. aylarda ve yıllık olarak pelvik muayene, VAS, öksürük stress testi (CST) ve ICIQ-SF ile değerlendirildi. Cerrahi sonuclar, sübjektif ve objektif iyileșme oranları ile ișlemle ilișili komplikasyonlar not edildi. İstatiksel analizler SPSS 17.0 programı (SPSS version 17.0, Chicago, IL, USA) kullanılarak yapıldı.

Bulgular: Çalıșma kriterlerine uygun olan toplam 67 hasta çalıșmaya dahil edildi. Objektif iyileșme, sübjektif iyileșme ve hasta memnuniyet oranları sırasıyla $\% 89,6, \% 53,7$ ve $\% 70,1$ olarak bulundu. Postoperatif 5 . yıl ICIQ-SF skoru >0 olan 29 hastanın ortalama skoru 12,2 (SD $\pm 4,2$ ) idi. 67 hastadan, 12 hastanın (\%17.9) urge üriner inkontinans (UUI) șikayeti postoperatif dönemde iyilești. Postoperatif dönemde UUI șikayeti devam eden 55 (\%82) hastaya antimuskarinik ilaç tedavisi bașlandı. Hiçbir hastada intraoperatif komplikasyon izlenmedi. Takip sırasında iki hasta (\%3) rekürren stres üriner inkontinans (SUI) nedeniyle tekrar opere edildi.

Sonuç: Uzun dönemde TOT, baskın komponenti SUI olan MUI hastalarının cerrahi tedavisinde bașarılı bir yöntemdir. Çoğu kadın için operasyon tatmin edicidir. UUI'ın devam etmesi hasta memnuniyetsizliğinin temel nedenidir.

Anahtar Sözcükler: TOT, miks üriner inkontinans, stres üriner inkontinans

Mixed urinary incontinence (MUI) is the coexistence of stress and urgency urinary incontinence and is defined as involuntary loss of urine associated with the sensation of urgency and also associated with exertion, effort, sneezing or coughing (1). In a community based study, it was reported that $36 \%$ of women with urinary incontinence had MUI (2). 
The lack of clarity awareness regarding the real clinical picture makes diagnosis and management extremely difficult (3). MUI is considered more difficult to treat due to the need of mutually managing stress urinary incontinence and overactive bladder symptoms, with the latter often being unpredictable with evidence of flaring and remission of symptoms over time (4).

In the treatment of female stress urinary incontinence (SUI), minimal invasive surgical procedures such as transobturator tape (TOT) and tension-free vaginal tape (TVT) are most popular techniques. Both TOT and TVT have short operative and hospitalization times with acceptable complication rates. Most studies comparing TOT and TVT have not found significant differences between these two techniques concerning objective and subjective efficacy in SUI $(5,6)$. However postoperative complications including bladder and bowel perforation, pelvic hematoma seems to be less common in patients who underwent TOT (7).

There are variable data available regarding cure rate of MUI following midurethral sling surgery of both the stress and urge components. In a recent systematic review and metaanalysis Jain et al (1) examined the effectiveness of MUS in women with MUI. The authors showed that MUS is associated with reasonable overall subjective cure rates in women with MUI. However, there was a wide variation in the cure rate of urgency and urgency urinary incontinence (UUI). The cure rate for overactive bladder $(\mathrm{OAB})$ was lower than for SUI and decreased with time. TOT is theoretically more advantageous in women with MUI compared to TVT due to the more horizontal insertion and less obstructive nature (1).

There is ongoing discussion for the best treatment approach to the patients with MUI. Without results of longterm follow-up comparative studies, it is not possible to conclude the efficacy of surgical procedures in
MUI. In the current study, our aim is to evaluate the success and complications of TOT procedure in the treatment of patients with MUI.

\section{MATERIALS AND METHODS}

We analyzed 193 consecutive female patients who underwent TOT procedure for SUI in two institutions from March 2005 to March 2009. Among these patients 75 women with MUI were the subjects of this study. All MUI patients had predominant SUI. All patients underwent standard outside-in TOT procedure as Delorme (8) described and data of the patients were retrospectively documented. All operations were performed using two brands which have the same characteristics (Heine Medizin ${ }^{\circledR}$ urethral support system, Düsseldorf, Germany and I-STOP $®$ CL Medical, Lyon, France). Both of them are macropore monofilament polypropylene meshes. Eligible women were at least 21 years old and had documented SUI or MUI (shown by urodynamic studies (UDS) and/or preoperative evaluation) and had completed the 5 years follow-up period. Patients with neurological disorder history, previous urethral reconstruction, morbid obesity and pelvic organ prolapse (POP) greater than stage 1 were excluded from the study. None of the patients experienced incontinence and/or gynecological surgery previously and underwent concomitant vaginal surgery. Preoperatively all patients filled in the informed consent form explaining the possible outcomes and complications of the procedure in detail.

All patients were preoperatively evaluated with history, pelvic examination in lithotomy position, urinary system ultrasound scan (US) and cough stress test (CST). Patients' characteristics including age, body mass index (BMI), the number of postmenopausal women, parity, the number of pads used daily, follow-up time, previous surgery and post voiding residual urine volume (PVR) were noted. All patients filled in the International Consultation on Incontinence Questionnaire-Short form (ICIQ-SF) preoperatively and at the postoperative follow-up visits. Visual analog scale (VAS) was used to evaluate postoperative patient satisfaction. In VAS, a score of 0 represented very dissatisfied / intolerable urinary complaints and 100 represented very satisfied / no urinary problems $(1,9)$. The patient was accepted as satisfied if the VAS score was $\geq 80$. POP was described during a maximal Valsalva maneuver using the POP quantification system (POP-Q). All patients underwent UDS evaluation (cystometry, pressure-flow study).

All patients were routinely evaluated on the postoperative 15 th day with urine culture and possible early postoperative complications were examined. Patients were evaluated on the postoperative $3 \mathrm{rd}$, 12th months and annually with pelvic examination, VAS, CST and ICIQ-SF. Surgical outcomes were evaluated and data of subjective and objective cure rates, any complications related to the procedure were registered. Objective cure was defined as a negative CST, no need for pads and no reoperation for SUI. The criteria for subjective cure included a score of 0 point from ICIQ-SF, no need for pads and no operation for SUI. All other outcomes were defined as failure. Cure of UUI was evaluated according to the patients' stating on ICIQ-SF and no need for antimuscarinic treatment. Statistical analyses were performed with SPSS 17.0 (SPSS version 17.0, Chicago, IL, USA).

\section{RESULTS}

A total of 67 women met the requirements for inclusion and had sufficient records for analysis. TOT procedure performed under spinal anesthesia in $65(97 \%)$ patients and under general anesthesia in $2(3 \%)$. 
Patients' characteristics were shown in table 1. According to electronic records UDS had revealed detrusor over-activity (DO) in 32 women $(47.7 \%)$ and urodynamic SUI (USUI) in 59 women (88\%) among 67 women with MUI. 24 women $(35.8 \%)$ had showed both USUI and DO.

Table 2 summarizes objective cure, subjective cure and patient satisfaction rates at the end of 5 year follow-up. The mean score for 29 patients with a postoperative 5 th year ICIQ-SF score $>0$ was 12.2 (SD \pm 4.2).

Of the 67 patients, the UUI component of 12 patients $(17.9 \%)$ had resolved postoperatively. Fifty-five $(82 \%)$ patients with persistent UUI postoperatively were treated with antimuscarinic drugs.
Overall, postoperative complication rate was $8.9 \%$ (Table 3). Table 3 summarizes the surgical complications reported according to modified Clavien classification. None of our patients experienced intraoperative complications. Two $(3 \%)$ patients required re-operation for recurrent SUI in the follow-up.
Table 1: Patients' demographic and preoperative characteristics

\begin{tabular}{|l|l|}
\hline Number of patients $(n)$ & 67 \\
\hline Age (year) mean $\pm S D$ & $52.7 \pm 8.4$ \\
\hline$B M I\left(\mathrm{~kg} / \mathrm{m}^{2}\right)$ mean $\pm S D$ & $29.2 \pm 2.5$ \\
\hline Number of postmenopausal women $n(\%)$ & $31(46.3)$ \\
\hline Parity median (range) & $2(0-5)$ \\
\hline Daily pad use median (range) & $4(2-9)$ \\
\hline Follow-up time (month) mean $\pm S D$ (range) & $69.67 \pm 11.1(60-96)$ \\
\hline Preoperative ICIQ-SF score mean $\pm S D$ & $17.13 \pm 3.4$ \\
\hline
\end{tabular}

$S D$, standard deviation;

$B M I$, body mass index:

ICIQ-SF, International Consultation on Incontinence

Questionnaire-Short Form
Table 2: Outcomes of the patients at the postoperative $5^{\text {th }}$ year

\begin{tabular}{|l|l|}
\hline Total, $n(\%)$ & $67(100)$ \\
\hline Objective cure, $n(\%)$ & $60(89.6)$ \\
\hline Subjective cure, $n(\%)$ & $36(53.7)$ \\
\hline Patient satisfaction (VAS score $\geq 80), n(\%)$ & $47(70.1)$ \\
\hline
\end{tabular}

VAS, visual analog scale

$n$, number of patients

Table 3: Postoperative complications listed according to modified Clavien cllassification system

\begin{tabular}{|l|c|}
\hline Total complication rate & $6(8.9 \%)$ \\
\hline Grade 1 & $1(16.7 \%)$ \\
\hline Dyspareunia/sexual discomfort & $4(66,6 \%)$ \\
\hline Grade 2 & - \\
\hline De novo urgency & 2 \\
\hline Severe groin and/or leg pain & 1 \\
\hline Urinary tract infection & 1 \\
\hline Vaginal mesh extrusion, local estrogen application & $1(16,7 \%)$ \\
\hline Grade 3a & 1 \\
\hline Urinary retention, prolonged urethral catheterization & \\
\hline Grade 3b & \\
\hline Urinary retention, mesh incision & - \\
\hline Vaginal mesh extrusion, mesh removing & - \\
\hline
\end{tabular}

\section{DISCUSSION}

MUI, which is considered as a combination of SUI and UUI, is highly prevalent in everyday practice (3). Semantic definitions of urge predominant MUI or stress predominant MUI were introduced to facilitate practical use and orient treatment (3). There is a paucity of primary research in this area and management of women with urodynamic MUI remains a subject of debate (9). MUI treatment consists of conservative management, pharmacotherapy and surgery. For women with predominant SUI, surgery is the most preferred treatment option but patients should be closely informed about possible 
postoperative additional treatments. Also before deciding for surgery, all treatment alternatives should be explained to the patient. The best approach has not been defined yet (3). In the current study, our aim is to evaluate our TOT surgery results in patients with MUI. Our study represents long term follow-up, high patient compliance, use of validated questionnaire to evaluate subjective and objective cure rates.

In a prospective randomized study comparing TVT and TOT in patients with SUI or MUI, Nyyssönen et al (10) showed that a large proportion of patients with MUI found the operation beneficial for urge symptoms. In a median follow-up of 46 months, the subjective and objective cure rates in TOT group were $81 \%$ and $74 \%$, respectively. Urge symptoms were relieved in $70 \%$ of patients in MUI subgroup. In another study, Gamble et al (11) assessed the efficacy of transobturator, retropubic or bladder neck sling in 305 women with MUI and concluded that transobturator slings had the lowest rate of persistent DO. Paick et al. (12) reported on 144 women with MUI who underwent TVT, SPARC or TOT and found similar cure rates in all three groups for SUI $(96 \%, 90 \%$, and $94 \%$, respectively) and UUI ( urge urinary incontinence) ( $82 \%$, $86 \%$ and $82 \%$, respectively). They also reported that preoperative low maximum urethral closure pressure and DO were both associated with increased likelihood of treatment failure of UUI. In a prospective, multi-centre, randomized study comparing TVT and TOT procedures for MUI, Kocjancic et al. (13) analyzed 116 women with SUI or MUI and randomized to TVT or TOT. They reported de novo urgency as the most frequent late complication. The storage symptom cure rate was 31\% after TVT and $55 \%$ after TOT. In the current study, although objective cure and patient satisfaction rates were high, the subjective cure rate was relatively low. This can be explained by the considerable effect of persistent UUI on subjective cure rates. Aging process directly affects the prevalence of UUI so the subjective cure rate decreases in the long-term follow-up (14). In addition to long-term followup, the definition of cure in our study was also responsible from low subjective cure rate. Definition of cure varied between different studies may be the possible reason for the variable success rates in different studies $(1,15)$. In a study with large number of patients, observed subjective cure was $60 \%$ at 7 months and $53.8 \%$ at 38 months when cure rate was defined as stress and urge indices of two or less episode of incontinence one to four times a month or less. However when cure was defined as complete dryness, the subjective cure rate dropped to $35.9 \%$ at 7 months and $28.4 \%$ after 38 months In our study we found approximately $20 \%$ subjective cure rate at minimum 5 year follow-up (16). The prevalence rates of urinary incontinence subtype varied with responders' age, ethnicity, how the question was asked, and how the subtype was defined $(17,18)$. We use the definition of cure in patients with UUI or MUI only in women who were completely dry. An available explanation why UUI may improve after surgery is that midurethral slings prevent urine from entering into the upper posterior urethra with increase in intra-abdominal pressure thereby avoiding reflex urine leak (19). In fact, tape is located under midurethra or distal urethra instead of proximal urethra in a successful TOT procedure (20).

Coyne et al (21) assessed the impact on health-related quality of life of stress, urge and MUI. The authors found that patients with MUI and UUI scored worse than those with SUI but no significant differences were found in quality of life (QoL) scores in patients with MUI and UUI. These findings were interpreted as urgency in mixed incontinence had a greater impact on quality of life than stress.
Patient satisfaction showing the effect of surgical treatment on the patients' QoL should be a matter of discussion in a study examining the results and efficacy of incontinence surgery. In a recent trial by our study group, patient satisfaction after TOT at the postoperative $1 \mathrm{st}$ and 5 th year was found to be $92 \%$ and $73 \%$, respectively (22). It is hard to evaluate patient satisfaction objectively due to several factors including surgical outcomes or complications which have direct impacts on the patients' expectations. Postoperative incontinence of any kind reduces patient satisfaction (23). In the present study, persistence of UUI was the main reason for dissatisfaction of the patients.

UDS are generally recommended before invasive procedures and surgery in MUI patients. UDS is an invasive and distressing procedure with a significant cost. Nager et al. (24) proved that preoperative UDS is not superior to office evaluation of UUI before surgery in terms of treatment success and patient satisfaction. UDS failed to identify SUI in eight (11.9\%) patients, but we have done TOT because of positive CST and SUI history. Also we could not confirm DO in 21 (31.3\%) patients who had incontinence with strong urge. When there is a disagreement between the UDS and the patient's symptoms, UDS findings are not superior to the patient's symptoms. Failure to demonstrate DO or SUI on UDS does not exclude the importance of patient' s symptoms (25).

In our study, overall complication rate of $8.9 \%$ was comparable to other studies with the complication rates ranging $10.5 \%$ to $31.3 \%(22,26)$. It has been advocated that de novo urgency rate is lower in TOT compared to other midurethral sling procedures (26). None of the patients experienced worsening of UUI. Also we had one vaginal erosion and one urinary retention. We did not remove the sling in both of the cases. In the patient with vaginal erosion, local 
estrogen application was enough and the other patient with urinary retention is treated with transient bladder catheterization.

Our study has some limitations. There was little data on daily pad use after surgery. If the patient was accepted as failure, questioning the daily pad use was omitted in most of the

\section{REFERENCES}

1. Jain P, Jirschele K, Botrus SM, Latthe PM. Effectiveness of midurethral slings in mixed urinary incontinence: a systematic review and meta-analysis. Int Urogynecol J 2011; 22: 923-932.

2. Hannestad YS, Rortveit G, Sandvik H, et al. A community-based epidemiological survey of female incontinence: the Norwegian EPINCONT study. Epidemiology of Incontinence County of Nord-Trondelag. J Clin Epidemiol 2000; 53: 1150-1157.

3. Porena M, Costantini E, Lazzeri M. Mixed Incontinence: How best to manage it? Curr Bladder Dysfunct Rep 2013; 8: 7-12.

4. Irwin DE, Milsom I, Chancellor MB, et al. Dynamic progression of overactive bladder and urinary incontinence symptoms: a systematic review. Eur Urol 2010; 58: 532-543.

5. Richter HE, Albo ME, Zyczynski HM, et al. Retropubic versus transobturator midurethral slings for stres incontinence. N Engl J Med 2010; 362: 2066-2076.

6. Latthe PM, Foon R, Toozs-Hobson P. Transobturator and retropubic tape procedures in stress urinary incontinence: a systematic review and meta-analysis of effectiveness and complications. BJOG 2007; 114: 522531.

7. Novara G, Artibani W, Barber MD, et al. Updated systematic review and metaanalysis of the comperative data on colposuspensions, pubovaginal slings and midurethral tapes in the surgical treatment of female stres urinary incontinence. Eur Urol 2010; 58: 218238. patients. Also postoperative UDS were performed only in case of worsening for UUI, not in all of the patients.

\section{CONCLUSION}

TOT procedure is successful for surgical treatment of MUI with predominant SUI in long-term follow-up. The

8. Delorme E. Transobturator urethral suspension: mini-invasive procedure in the treatment of stress urinary incontinence in women. Prog Urol. 2001;11:1306-1313.

9. Abdel-fattah M, Mostafa A, Young D, et al. Evaluation of transobturator tensionfree vaginal tape in the management of women with mixed urinary incontinence: one-year outcomes. Am J Obstet Gynecol 2011; 205: 150.e1-6.

10. Nyyssönen V, Talvensaari-Mattila A, Sanatala M. A prospective randomized trial comparing tension-free vaginal tape versus transobturator tape in patients with stress or mixed urinary incontinence: subjective cure rate and satisfaction in median follow-up of 46 months. Scandinavian J Urol 2014; 48: 309-315.

11. Gamble TL, Botros SM, Beaumont JL, et al. Predictors of persistent detrusor overactivity after transvaginal sling procedures. Am J Obstet Gynecol 2008; 199: 696. e 1-7.

12. Paick JS, Oh SJ, Kim SWet al. Tensionfree vaginal tape, suprapubic arc sling, and transobturator tape in the treatment of mixed urinary incontinence in women. Int Urogynecol J Pelvic Floor Dysfuction 2008; 19: 123-129.

13. Kocjancic E, Costantini E, Frea B, et al. Tension free vaginal tape vs transobturator tape: is there any difference in the mixed incontinence patients? Results of multicentre randomized trial. Eur Urol 2008; Suppl 7(3): 123. Abstr 209.

14. Milsom I, Coyne KS, Nicholson S, et al. Global prevalance and economic burden of urgency urinary incontinence: a systematic review. Eur Urol 2014; 65: 79-95. majority of women found the operation satisfactory. Persistence of UUI was the main reason for dissatisfaction. Long-term comparative studies are needed to assess the efficacy of TOT in patients with MUI.

15. Rapp DE, Kobashi KC. Outcomes following sling surgery: importance of defination of success. J Urol 2008; 180: 998-1002.

16. Kulseng-Hanssen K, Husby H, Schiotz HA. Follow-up of TVT operations in 1,113 women with mixed urinary incontinence at 7 and 38 months. Int Urogynecol J 2008; 19:391-396.

17. Peyrat L, Haillot O, Bruyere F, et al. Prevalance and risk factors of urinary incontinence in young and middle-aged women. BJU Int 2002; 89: 61-66.

18. Kenton K, Mueller ER. The global burden of female pelvic floor disorders. BJU Int 2006; 98 Suppl 1:1-5.

19. Minassian VA, Stewart WF, Hirsch AG. Why do stress and urge incontinence co-occur much more often than expected ? Int Urogynecol J Pelvic Floor Dysfunction 2008; 19: 1429-1440.

20. Bogusiewicz M, Monist M, Galczynski $\mathrm{K}$, et al. Both the middle and distal sections of the urethra may be regarded as optimal targets for 'outside-in' transobturator tape placement. World J Urol 2014 Feb 17 ( Epub ahead of print ).

21. Coyne KS, Zhou Z, Thompson C, et al. The impact on health-related quality of life of stress, urge and mixed urinary incontinence. BJU Int 2003; 92: 731735.

22. Yonguç T, Gunlusoy B, Degirmenci T, et al. Are the outcomes of transobturator tape procedure for female stress incontinence durable in long-term follow-up ? Int Urol Nephrol 2014; 46 (7): 1295-1300.

23. Mahajan ST, Elkadry EA, Kenton KS, et al. Patient-centered surgical outcomes: the impact of goal achievement and urge incontinence on 
patient satisfaction one year after surgery. Am J Obstet Gynecol 2006; 194: 722-728.

24. Nager CW, Brubaker L, Litman HJ, et al. A randomized trial of urodynamic testing before stress incontinence surgery. N Engl J Med 2012; 366: 19871997.
25. Scarpero H. Urodynamics in the evaluation of female LUTS: When are they helpful and how do we use them ? Urol Clin North Am 2014; 41: 429-438.

26. Novara G, Artibani W, Barber MD, et al. Updated systematic review and meta-analysis of the comperative data on colposuspension, pubovaginal slings and midurethal tapes in the surgical treatment of female stress urinary incontinence. Eur Urol 2010; 58: 218 238. 